University of Nebraska - Lincoln

DigitalCommons@University of Nebraska - Lincoln

USDA National Wildlife Research Center - Staff Publications
U.S. Department of Agriculture: Animal and Plant Health Inspection Service

2005

\title{
Serologic Evidence Of Exposure Of Wild Mammals To Flaviviruses In The Central And Eastern United States
}

\author{
J. Jeffrey Root \\ Colorado State University, jeff.root@aphis.usda.gov \\ Jeffrey S. Hall \\ Colorado State University \\ Robert G. Mclean \\ Colorado State University \\ Nicole L. Marlenee \\ Colorado State University \\ Barry J. Beaty \\ Colorado State University
}

See next page for additional authors

Follow this and additional works at: https://digitalcommons.unl.edu/icwdm_usdanwrc

Part of the Environmental Sciences Commons

Root, J. Jeffrey; Hall, Jeffrey S.; Mclean, Robert G.; Marlenee, Nicole L.; Beaty, Barry J.; Gansowski, Justin; and Clark, Larry, "Serologic Evidence Of Exposure Of Wild Mammals To Flaviviruses In The Central And Eastern United States" (2005). USDA National Wildlife Research Center - Staff Publications. 1062.

https://digitalcommons.unl.edu/icwdm_usdanwrc/1062

This Article is brought to you for free and open access by the U.S. Department of Agriculture: Animal and Plant Health Inspection Service at DigitalCommons@University of Nebraska - Lincoln. It has been accepted for inclusion in USDA National Wildlife Research Center - Staff Publications by an authorized administrator of DigitalCommons@University of Nebraska - Lincoln. 


\section{Authors}

J. Jeffrey Root, Jeffrey S. Hall, Robert G. Mclean, Nicole L. Marlenee, Barry J. Beaty, Justin Gansowski, and Larry Clark 


\title{
SEROLOGIC EVIDENCE OF EXPOSURE OF WILD MAMMALS TO FLAVIVIRUSES IN THE CENTRAL AND EASTERN UNITED STATES
}

\section{J. JEFFREY ROOT, JEFFREY S. HALL, ROBERT G. MCLEAN, NICOLE L. MARLENEE, BARRY J. BEATY,} JUSTIN GANSOWSKI, AND LARRY CLARK

National Wildlife Research Center, USDA/APHIS/WS, Fort Collins, Colorado; Arthropod-borne and Infectious Diseases Laboratory, Department of Microbiology, Immunology, and Pathology, Colorado State University, Fort Collins, Colorado; New York Wildlife Services, USDA, Castleton, New York

\begin{abstract}
Serosurveys were conducted to obtain flavivirus and West Nile virus (WNV) seroprevalence data from mammals. Sera from 513 small- and medium-sized mammals collected during late summer and fall 2003 from Colorado, Louisiana, New York, Ohio, and Pennsylvania were screened for flavivirus-specific antibodies. Sera samples containing antibody to flaviviruses were screened for WNV-specific antibodies by epitope-blocking enzyme-linked immunosorbent assays and confirmed with plaque reduction neutralization tests. Prevalence of WNV antibodies among study sites ranged from $0 \%$ to $42.8 \%$ among the mammal communities sampled. High prevalence rates for WNV were noted among raccoons $(100 \%$, with a very small sample size, $N=2)$, Virginia opossums $(50.0 \%)$, fox squirrels $(49.1 \%)$, and eastern gray squirrels $(48.3 \%)$. The high WNV antibody prevalence noted for tree squirrels, the peri-domestic tendencies of several of these species, and their ease of observation could make these species useful sentinels for monitoring WNV activity within urban communities.
\end{abstract}

\section{INTRODUCTION}

In late summer 1999, New York City and neighboring counties in New York State experienced an outbreak of arboviral encephalitis, ${ }^{1}$ which was concurrent with extensive mortality in crows (Corvus spp.). ${ }^{2}$ The etiologic agent for both humans and birds was determined to be West Nile virus (WNV; family Flaviviridae, genus Flavivirus). ${ }^{3}$ The virus spread rapidly across the United States with activity recognized in at least 46 states and the District of Columbia by $2003^{4}$ and has recently been documented in Mexico, ${ }^{5}$ the Dominican Republic, ${ }^{6}$ and Jamaica. ${ }^{7}$

$\mathrm{WNV}$ is a mosquito-borne virus that is a member of the Japanese encephalitis virus complex. ${ }^{8}$ Although WNV can infect a wide range of vertebrates, ${ }^{1}$ the natural transmission cycle of WNV involves the transmission of the virus to birds by mosquito vectors. ${ }^{9}$ Many species of wild birds act as vertebrate hosts, ${ }^{10}$ but mammals are presumed to serve as deadend hosts. ${ }^{11}$ Laboratory investigations indicated that several North American mosquito species could serve as potential vectors for WNV. ${ }^{12}$ Although some mosquito species are ornithophilic, others have opportunistic feeding habits, potentially bridging WNV transmission between birds and mammals. ${ }^{13}$ For example, Culex tarsalis is known to feed primarily upon birds in the spring but often feeds upon mammals by midsummer. ${ }^{14}$

Observational and experimental studies suggest that prey to predator transmission of WNV is possible for birds ${ }^{15,16}$ and a recent experimental study has suggested this route of transmission is possible in mammals. ${ }^{17}$ Furthermore, experimental studies have indicated that contact transmission of WNV among crows is possible, most likely orally via WNV-laden discharges. ${ }^{18}$ Recent work supports this observation for five of 18 species tested, including American crows (Corvus brachyrhynchos). ${ }^{16}$

Within its historical geographic distribution in parts of the Old World, crows with antibodies to WNV are common, indicating that asymptomatic infection or mild disease occurs among crows in those localities. ${ }^{1}$ In contrast, the strain of WNV circulating in the United States causes significant mortality in some bird species, especially in the American crow. ${ }^{18}$ Thus, there is a variety of responses to infection in hosts with different strains of WNV. ${ }^{9}$
For mammals, WNV is well known to cause disease and occasionally death in horses ${ }^{19}$ and humans. ${ }^{3}$

Although many WNV serosurveys have been conducted on birds, few have been conducted on mammals, especially in the New World. Thus, systematic serosurveys for WNV in mammals are needed to ascertain the exposure rates of these species. In New York, where WNV was first introduced into the United States, evidence of WNV (e.g., antibodies or viral RNA) was detected in horses and $\operatorname{dogs},{ }^{20}$ in $8 \%$ of tested mammals within the Bronx Zoo/Wildlife Conservation Park in $1999,{ }^{10}$ and in one little brown bat (Myotis lucifugus), one big brown bat (Eptesicus fuscus), one eastern gray squirrel (Sciurus carolinensis), one domestic rabbit (Oryctolagus cuniculus), and one eastern chipmunk (Tamias striatus) in $2000 .^{21}$ Additional evidence of WNV exposure has been obtained from a striped skunk in Connecticut ${ }^{22}$ and black bears (Ursus americanus) in New Jersey. ${ }^{23}$ By 2003, evidence of WNV infection was reported in thousands of non-human mammals, most being livestock or companion animals. ${ }^{4}$

We sampled small- and medium-sized mammals for antibodies to flaviviruses and WNV as an index of exposure to flaviviruses in wild, peri-domestic mammals in several geographic locations in the United States. Many of the mammals sampled reflect their importance as peri-domestic species, often being characterized by large population sizes in past WNV epizootic areas. Our objective was to obtain seroprevalence data of mammals to assess the potential of various mammal species to serve as indicator species of WNV activity and as potential reservoirs of WNV.

\section{MATERIALS AND METHODS}

Study sites. Study sites were established in Colorado, Louisiana, New York, Pennsylvania, and Ohio (Figure 1). These states were selected because of their high levels of WNV activity over one or more of the years following the 1999 outbreak in New York. The number of locations sampled in each state and trapping effort among sites varied because of prevailing circumstances, but the objective was to sample at least four locations per state.

In Colorado, a total of six study sites were sampled in Larimer County, a focal area experiencing epizootic and epi- 


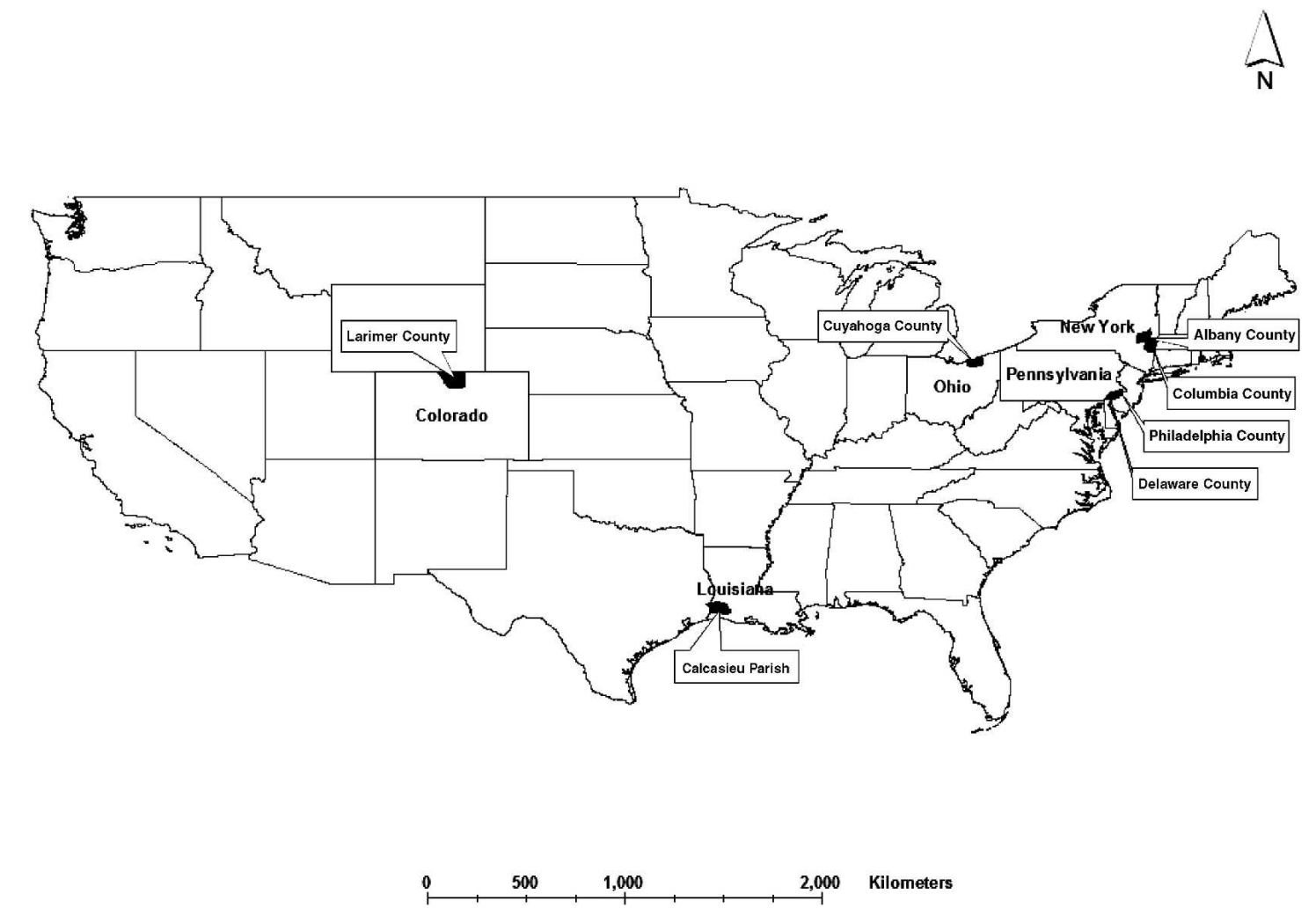

FIGURE 1. Study sites for mammalian flavivirus serosurveys in the central and eastern United States, 2003.

demic activity in $2003 .{ }^{4}$ These study sites included four sites (some atypical, see below) located within an agricultural complex in Fort Collins (FSA, FSB, FSC, and FSD), a single site located within a city Natural Area (MNA), and a single site located at a landfill (LCL). In Louisiana, four study sites were sampled within Calcasieu Parish (SLA, SLB, SLC, and SLD); all were located on a single private property. In New York, four study sites were sampled. These sites included two landfills (ALF and CLF) in Albany County, and two privately owned farms (PRE and BAR), both located in Columbia County. Three cemeteries were sampled (4 total study sites: BHA, BHB, HCC, and HSC) in the greater Cleveland area of Ohio (Cuyahoga County), and four sites were sampled in Pennsylvania, three in Philadelphia County (TSB, PSA, and PSB), and one in Delaware County (TSA).

Field sampling. Mammals were sampled using Sherman folding, aluminum live-traps $\left(3.5 \times 3.5 \times 10^{\prime \prime}\right)$ and two sizes of wire mesh collapsible Tomahawk live-traps $\left(5 \times 5 \times 16^{\prime \prime}\right.$ and 6 $\left.\times 6 \times 19^{\prime \prime}\right)$ to target a variety of small- to medium-sized mammals. Traps were baited with peanut butter, rolled oats and/or oatmeal.

Within each study site a trap-line was situated according to available edge habitat (e.g., forest-open space edge). Each trap-line consisted of 25 trap-stations. Trap-stations were set at intervals of approximately $20 \mathrm{~m}$. Each trap-station consisted of two Sherman traps and two Tomahawk traps (one of each size listed above). At each trap-station, traps were set approximately $5 \mathrm{~m}$ apart. Trap-lines were maintained (baited and checked) for 4 consecutive days (i.e., 400 trap-nights per location), after which the traps were removed and made available for additional trapping efforts. Atypical transects were used when insufficient edge habitat was available. Further,
400 trap-nights were not conducted at some study sites due to logistical considerations (e.g., Hurricane Isabel and trap disturbance). All trapping was conducted August-November 2003.

Mammal processing. Mammals were live trapped and euthanized with $\mathrm{CO}_{2}$ in locales that permitted lethal study. In these locations, blood was drawn via cardiac puncture. Blood was placed in Microtainer tubes and kept on wet ice $\left(0^{\circ} \mathrm{C}\right)$ until centrifuged (usually several hours after initial collection). The serum was preserved at $-20^{\circ} \mathrm{C}$ for shipping and stored at $-70^{\circ} \mathrm{C}$ in the laboratory for analysis. Oral swabs and select tissues were harvested from each animal. Analyses of tissues and oral swabs will be the focus of future studies.

In $\mathrm{CO}$ and $\mathrm{PA}$, in areas where lethal collection was not always permitted, mammals were live trapped, marked with individually numbered ear tags, and released. In these locations, animals were lightly anesthetized using isoflurane, and blood (via retro-orbital plexus or nail quik) and oral swab samples were obtained. Blood and oral swab samples were processed as listed above. Following recovery from anesthesia, animals were released at their point of capture. All animal field methods were approved by the National Wildlife Research Center's Institutional Animal Care and Use Committee.

Laboratory analyses. Epitope-blocking enzyme-linked immunosorbent assays (ELISA) using monoclonal antibodies (6B6C-1, a cross reactive flavivirus antibody which detects an E protein epitope; $3.1112 \mathrm{G}$, a WNV-specific antibody which detects an NS1 epitope) to flaviviruses and WNV were performed by the method of Blitvich and others ${ }^{11}$ at the National Wildlife Research Center. This blocking ELISA technique is species independent and does not require species-specific an- 
tibodies. Sera antibody positive for flaviviruses (e.g., 6B6C-1) were screened for WNV. Sera positive for antibodies to WNV by blocking ELISA were tested by plaque reduction neutralization tests (PRNT) to identify the infecting virus. ${ }^{24}$ Additional borderline positive and control samples were tested. These analyses were conducted at the Arthropod-borne and Infectious Diseases Laboratory, Colorado State University. PRNTs were performed using WNV (strain NY99-35261-11) and Saint Louis encephalitis virus (SLEV; strain TBH-28). SLEV was included in these experiments because it has been identified in several of our study areas and is known to crossreact to anti-WNV neutralizing antibodies. ${ }^{25}$ Viruses were obtained from the World Health Organization Center for Arbovirus Reference and Research maintained at the Centers for Disease Control and Prevention, Division of VectorBorne Infectious Diseases, Fort Collins, CO. PRNTs were performed using Vero cells. Sera were initially tested at a dilution of 1:20. Specimens that reduced the number of plaques by $70 \%$ were titrated $\left(\mathrm{PRNT}_{70}\right)$. Titers were expressed as the reciprocal of serum dilutions yielding $\geq 90 \%$ reduction in the number of plaques $\left(\mathrm{PRNT}_{90}\right)$. For etiologic diagnosis, the $\mathrm{PRNT}_{90}$ antibody titer to the respective virus was required to be at least 4-fold greater than that of the other flavivirus tested. Occasionally, some sera samples were insufficient to conduct any or all tests.

\section{RESULTS}

In more than 7,000 trap-nights, we processed 609 small- to medium-sized mammals representing more than 20 species.
These mammals included 109 individuals from Colorado, 88 individuals from Louisiana, 194 individuals from New York, 155 individuals from Ohio, and 63 individuals from Pennsylvania (Tables 1-5). In some instances, inadequate or no serum samples were obtained to conduct several or all tests. Therefore, the prevalence of antibodies to flaviviruses, WNV, and PRNT confirmations reported herein were calculated from the total number of individuals tested for each test. Overall, sample sizes ranged from 2 to 61 among the 22 study sites sampled.

In Colorado, where the highest number of human WNV cases were reported in $2003,{ }^{4}$ prevalence of antibodies to flaviviruses in mammals ranged from $0 \%$ at LCL to $100 \%$ at MNA, with an overall average of $29 \%$ (Table 1). A total of 8 species were sampled in $\mathrm{CO}$, with evidence of flavivirus antibodies in five of eight (Table 1). These species included deer mice (Peromyscus maniculatus), house mice (Mus musculus), western harvest mice (Reithrodontomys megalotis), fox squirrels (Sciurus niger), and a single meadow vole (Microtus pennsylvanicus). Using the WNV specific monoclonal antibody (MAb; 3.1112G), antibodies to WNV were detected in fox squirrels and a house mouse (Table 1). PRNTs confirmed all WNV exposures in Colorado, and also indicated a single SLEV exposure in a black-tailed prairie dog (Cynomys ludovicianus; Table 1). Overall, the antibody prevalence of WNV in Colorado mammals was $3.0 \%$ (Table 1).

In Louisiana, prevalence of antibodies to flaviviruses in mammals ranged from $0-40 \%$ among study sites, with an overall average of $32.1 \%$ (Table 2). Antibodies to flaviviruses

TABLE 1

Summary of flavivirus and West Nile virus serological assays: Larimer County, Colorado, 2003

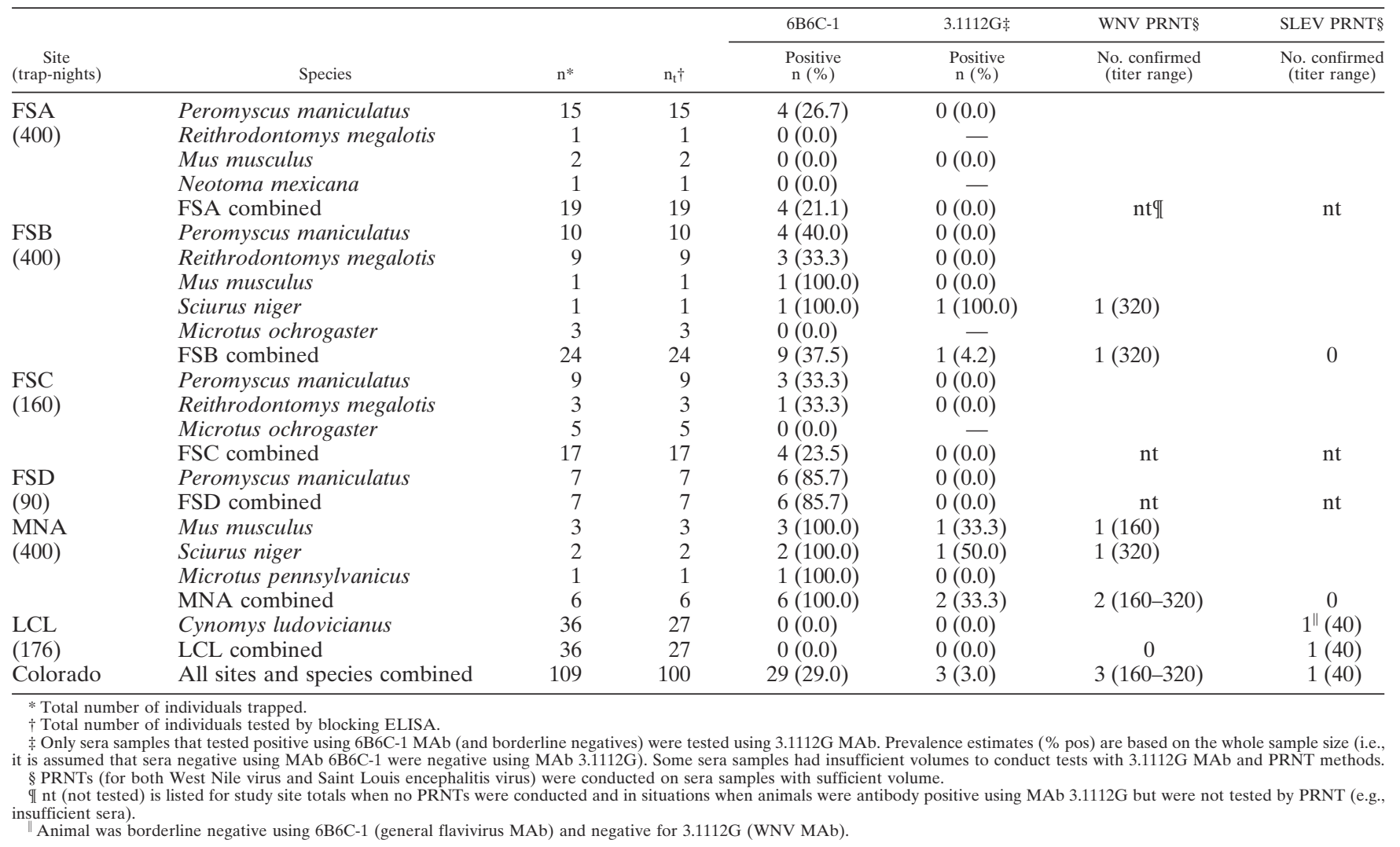


TABLE 2

Summary of flavivirus and West Nile virus serological assays: Calcasieu Parish, Louisiana, 2003

\begin{tabular}{|c|c|c|c|c|c|c|c|}
\hline \multirow[b]{2}{*}{$\begin{array}{c}\text { Site } \\
\text { (trap-nights) }\end{array}$} & \multirow[b]{2}{*}{ Species } & \multirow[b]{2}{*}{$\mathrm{n}^{*}$} & \multirow[b]{2}{*}{$\mathrm{n}_{\mathrm{t}}^{\dagger}$} & \multirow{2}{*}{$\begin{array}{c}\text { 6B6C-1 } \\
\begin{array}{c}\text { Positive } \\
\text { n (\%) }\end{array}\end{array}$} & \multirow{2}{*}{$\begin{array}{c}3.1112 \mathrm{G} \doteqdot \\
\text { Positive } \\
\text { n }(\%)\end{array}$} & \multirow{2}{*}{$\begin{array}{c}\text { WNV PRNT§ } \\
\begin{array}{c}\text { No. confirmed } \\
\text { (titer range) }\end{array}\end{array}$} & \multirow{2}{*}{$\frac{\text { SLEV PRNT§ }}{\begin{array}{c}\text { No. confirmed } \\
\text { (titer range) }\end{array}}$} \\
\hline & & & & & & & \\
\hline SLA & Mus musculus & 2 & 2 & $1(50.0)$ & - & & \\
\hline \multirow[t]{2}{*}{ (400) } & Rattus spp.II & 42 & 35 & $11(31.4)$ & $1(2.9)$ & $\mathrm{nt}^{\|}$ & $\mathrm{nt}$ \\
\hline & SLA combined & 44 & 37 & $12(32.4)$ & $1(2.7)$ & $\mathrm{nt}$ & $\mathrm{nt}$ \\
\hline SLB & Mus musculus & 11 & 5 & $2(40.0)$ & $0(0.0)$ & & \\
\hline \multirow{3}{*}{ (400) } & Rattus spp.II & 10 & 8 & $2(25.0)$ & $0(0.0)$ & & \\
\hline & Didelphis virginiana & 2 & 2 & $2(100.0)$ & $0(0.0)$ & & \\
\hline & SLB combined & 23 & 15 & $6(40.0)$ & $0(0.0)$ & $\mathrm{nt}$ & $\mathrm{nt}$ \\
\hline SLC & Mus musculus & 1 & 0 & - & - & & \\
\hline \multirow[t]{3}{*}{ (400) } & Rattus spp.I & 17 & 3 & $0(0.0)$ & $0(0.0)$ & & \\
\hline & Didelphis virginiana & 1 & 1 & $0(0.0)$ & - & & \\
\hline & SLC combined & 19 & 4 & $0(0.0)$ & $0(0.0)$ & $\mathrm{nt}$ & $\mathrm{nt}$ \\
\hline SLD & Mus musculus & 1 & 0 & $0(0.0)$ & - & & \\
\hline \multirow[t]{2}{*}{$(80)$} & Rattus spp.II & 1 & 0 & $0(0.0)$ & - & & \\
\hline & SLD combined & 2 & 0 & $0(0.0)$ & - & $\mathrm{nt}$ & $\mathrm{nt}$ \\
\hline Louisiana & All sites and species combined & 88 & 56 & $18(32.1)^{* *}$ & $1(1.8)$ & $\mathrm{nt}$ & $\mathrm{nt}$ \\
\hline
\end{tabular}

were detected in house mice, Old World rats (Rattus spp.), and Virginia opossums (Didelphis virginiana). Only a single Old World rat was positive for WNV when MAb 3.1112G was used (Table 2). The serum sample was insufficient to test this individual by PRNT. Overall, the antibody prevalence of WNV in Louisiana mammals was $1.8 \%$ (Table 2).

The New York study sites yielded the most diverse mammalian assemblage, which included thirteen species (Table 3). Prevalences of antibodies to flaviviruses ranged from 19.4\% at PRE to $53.7 \%$ at CLF, with an overall average of $30.1 \%$ (Table 3). Antibodies to flaviviruses were detected in eastern grey squirrels, short-tailed shrews (Blarina brevicauda), eastern chipmunks (Tamias striatus), Virginia opossums, deer mice and white-footed mice (Peromyscus spp.), a meadow vole, an eastern cottontail (Sylvilagus floridanus), a Norway rat (Rattus norvegicus), a meadow jumping mouse (Zapus hudsonius), and a woodland jumping mouse (Napaeozapus insignis). Eastern grey squirrels, Virginia opossums, and a meadow jumping mouse were positive for WNV by ELISA techniques using MAb 3.1112G (Table 3). For samples with sufficient serum, PRNT tests confirmed all of these tests (a total of four positive samples were not tested by PRNT), and also indicated the presence of antibodies to WNV in one red squirrel (Tamiasciurus hudsonicus) and in one Peromyscus mouse, and antibodies to SLEV in a congener. Overall, the antibody prevalence of WNV in New York mammals was $6.9 \%$ and site specific prevalences ranged from 0 at PRE to $19.5 \%$ at CLF (Table 3).

The Ohio study sites yielded a total of 10 small to mediumsized mammal species. Prevalences of antibodies to flaviviruses ranged from $44.9 \%$ at BHA to $58.3 \%$ at HCC. Flavivirus antibodies were detected in fox squirrels, short-tailed shrews, eastern chipmunks, Virginia opossums, house mice, and Peromyscus spp. WNV antibodies were detected in fox squirrels and a Virginia opossum using MAb 3.1112G. PRNTs confirmed these tests, and also indicated the presence of
WNV antibody in six Peromyscus mice (Table 4). Prevalences of antibodies to WNV ranged from $6.1 \%$ at BHA to $41.7 \%$ at HCC, with an overall average of $20.6 \%$ (Table 4).

At the Pennsylvania sites, trapping efforts were hindered by Hurricane Isabel. Nonetheless, antibodies to flaviviruses were detected in 23 of 53 mammals tested (overall prevalence $43.4 \%$; Table 5). Site specific prevalences ranged from $15.4 \%$ (TSB) to $75.0 \%$ (PSB; Table 5). Antibodies to flaviviruses were detected in eastern gray squirrels, short-tailed shrews, eastern chipmunks, Virginia opossums, Peromyscus mice, house mice, and raccoons (Procyon lotor). Antibodies to WNV were detected in eastern grey squirrels, Virginia opossums, and a raccoon using MAb 3.1112G (Table 5). PRNTs confirmed these tests, and also indicated WNV antibody in an additional raccoon. Prevalences of antibodies to WNV ranged from $0 \%$ at TSA to $42.8 \%$ at PSA, with an overall average of $17 \%$ (Table 5).

\section{DISCUSSION}

There is little information on the role of wild mammals in the epidemiology of WNV. The apparent insignificance of wild mammals in the ecology of WNV may be from lack of scrutiny rather than from lack of importance. ${ }^{9}$ Furthermore, few studies have surveyed for flavivirus antibodies in wild North American mammals. This study is the only systematic survey for flaviviruses of wild, peridomestic mammals from multiple geographic regions in the United States.

Flaviviruses. Exceptionally high antibody prevalence rates of flaviviruses were noted among several study sites and among several mammalian species. These rates were significantly reduced for WNV and SLEV, and may indicate exposure to one or more different, possibly undescribed, flaviviruses. A second scenario, however, is that the blocking ELISA technique using MAb 6B6C-1 may be sensitive to variations in serum samples (e.g., hemolysis of some samples). 
TABLE 3

Summary of flavivirus and West Nile virus serological assays: Albany and Columbia counties, New York, 2003

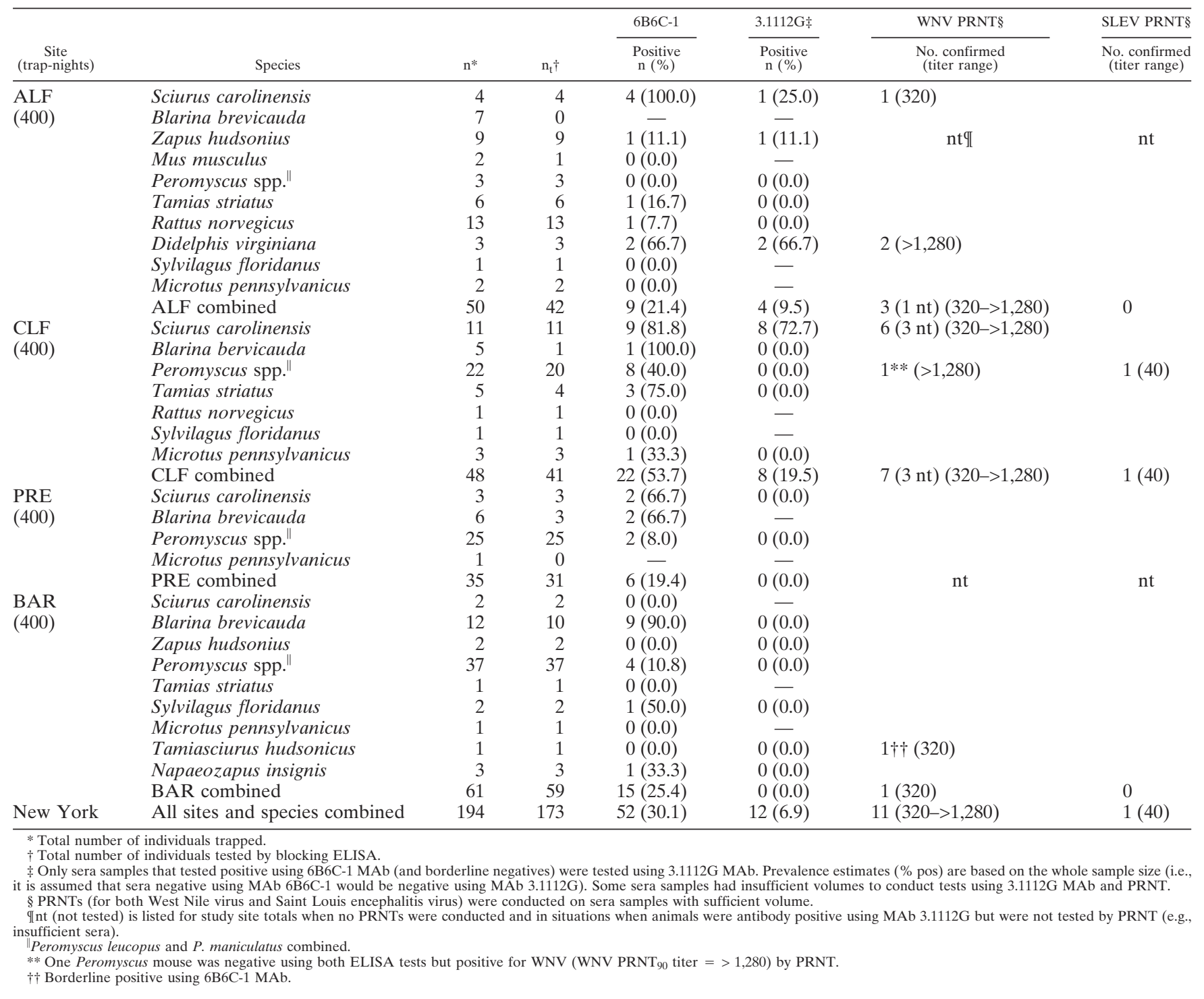

However, the blocking ELISA using MAb 3.1112G compared favorably with the PRNT for WNV (c.f. Blitvich and others) ${ }^{11}$ suggesting the comparability of these two assays for WNV. Regardless, the species specific patterns of results from assays using MAb 6B6C-1 are of interest.

Nearly $71 \%$ of short-tailed shrews were antibody positive for flaviviruses using MAb 6B6C-1 (Table 6). This may indicate that these shrews were infected with a flavivirus, other than WNV or SLEV. However, the majority of shrews died before they were processed. Therefore, blood samples (via cardiac puncture) were not necessarily of the same quality (i.e., increased occurrence of hemolysis) as was the case with most other species. However, nearly all the deer mice captured in Colorado were bled with capillary tubes, thereby decreasing the chance of hemolysis. Notably, the deer mouse yielded an overall antibody prevalence to flaviviruses of $41.5 \%$. These data strongly suggest that these mice are commonly exposed to one or more flaviviruses, some of which may be unrecognized.

Several flaviviruses have no known vectors and were first isolated in rodent hosts, ${ }^{26}$ many of which were recovered from apparently asymptomatic rodents. ${ }^{27}$ For example, Cowbone Ridge, Sal Vieja, San Perlita, and Modoc viruses were all first isolated from rodents from Florida, Texas, Texas, and the western United States, respectively. ${ }^{26}$ All of these viruses are assigned to the Modoc antigenic complex. ${ }^{26}$ Little systematic field work has been conducted on rodent-associated flaviviruses, especially in select geographic areas of the United States. Some flavivirus antibody positive rodents sampled in this study could have been exposed to one of the viruses assigned to the Modoc antigenic complex or to a flavivirus which has not been described.

Tree squirrels. The high prevalence of WNV antibodies in tree squirrels (Sciurus spp. and Tamiasciurus sp.) is of great interest. This observation was consistent among three species (albeit only a single red squirrel was sampled), four states, and the majority of study sites at which tree squirrels were captured. Notably, tree squirrels are one of the few wild mammals in North America for which evidence of WNV infection has been published. ${ }^{4}$ However, most data have been obtained 
TABLE 4

Summary of flavivirus and West Nile virus serological assays: Cuyahoga County, Ohio, 2003

\begin{tabular}{|c|c|c|c|c|c|c|c|}
\hline & & & & 6B6C-1 & $3.1112 \mathrm{G} \neq$ & WNV PRNT§ & SLEV PRNT\& \\
\hline $\begin{array}{c}\text { Site } \\
\text { (trap-nights) }\end{array}$ & Species & $\mathrm{n}^{*}$ & $\mathrm{n}_{\mathrm{t}}^{\dagger}$ & $\begin{array}{l}\text { Positive } \\
\text { n (\%) }\end{array}$ & $\begin{array}{l}\text { Positive } \\
\text { n (\%) }\end{array}$ & $\begin{array}{l}\text { No. confirmed } \\
\text { (titer range) }\end{array}$ & $\begin{array}{l}\text { No. confirmed } \\
\text { (titer range) }\end{array}$ \\
\hline BHA & Sciurus niger & 9 & 9 & $3(33.3)$ & $3(33.3)$ & $3(160->1,280)$ & \\
\hline \multirow[t]{5}{*}{$(400)$} & Mus musculus & 3 & 2 & $1(50.0)$ & - & & \\
\hline & Peromyscus spp.II & 30 & 27 & $17(63.0)$ & $0(0.0)$ & $4^{\|}(40-80)$ & \\
\hline & Tamias striatus & 12 & 10 & $1(10.0)$ & $0(0.0)$ & & \\
\hline & Didelphis virginiana & 1 & 1 & $0(0.0)$ & - & & \\
\hline & BHA combined & 55 & 49 & $22(44.9)$ & $3(6.1)$ & $7(40->1,280)$ & 0 \\
\hline $\mathrm{BHB}$ & Sciurus niger & 23 & 22 & $13(59.1)$ & $10(45.5)$ & $10(80->1,280)$ & \\
\hline \multirow[t]{5}{*}{$(400)$} & Peromyscus sppף & 13 & 10 & $3(30.0)$ & $0(0.0)$ & $2^{\|}(40-640)$ & \\
\hline & Tamias striatus & 1 & 1 & $0(0.0)$ & - & & \\
\hline & Marmota monax & 1 & 1 & $0(0.0)$ & - & & \\
\hline & Rattus norvegicus & 1 & 1 & $0(0.0)$ & - & & \\
\hline & BHB combined & 39 & 35 & $16(45.7)$ & $10(28.6)$ & $12(40->1,280)$ & 0 \\
\hline $\mathrm{HCC}$ & Sciurus niger & 6 & 5 & $5(100.0)$ & $5(100.0)$ & $5(640->1,280)$ & \\
\hline \multirow[t]{5}{*}{$(400)$} & Peromyscus spp.II & 4 & 4 & $1(25.0)$ & $0(0.0)$ & & \\
\hline & Tamias striatus & 1 & 1 & $1(100.0)$ & $0(0.0)$ & & \\
\hline & Microtus pennsylvanicus & 1 & 1 & $0(0.0)$ & - & & \\
\hline & Marmota monax & 1 & 1 & $0(0.0)$ & - & & \\
\hline & HCC combined & 13 & 12 & $7(58.3)$ & $5(41.7)$ & $5(640->1,280)$ & 0 \\
\hline $\mathrm{HSC}$ & Sciurus niger & 17 & 14 & $8(57.1)$ & $8(57.1)$ & $8(160->1,280)$ & \\
\hline \multirow[t]{5}{*}{ (400) } & Blarina brevicauda & 10 & 5 & $3(60.0)$ & $0(0.0)$ & & \\
\hline & Peromyscus spp.II & 11 & 6 & $3(50.0)$ & $0(0.0)$ & & \\
\hline & Tamias striatus & 9 & 9 & $2(22.2)$ & $0(0.0)$ & & \\
\hline & Didelphis virginiana & 1 & 1 & $1(100.0)$ & $1(100.0)$ & $1(>1,280)$ & \\
\hline & HSC combined & 48 & 35 & $17(48.6)$ & $9(25.7)$ & $9(160->1,280)$ & 0 \\
\hline Ohio & All sites and species combined & 155 & 131 & $62(47.3)$ & $27(20.6)$ & $33(40->1,280)$ & 0 \\
\hline
\end{tabular}

from dead or moribund squirrels. ${ }^{28,29}$ Data presented herein imply that high numbers of tree squirrels likely are exposed to WNV, but many survive and develop protective antibodies. Why squirrels, as compared with the 14 other rodent species tested, including sympatric chipmunks, had high WNV antibody prevalence $(48.3 \%$ and $49.1 \%$ for eastern gray and fox squirrels, respectively; Table 6) remains undetermined. However, several life history traits of these squirrels, such as their arboreal lifestyles, may help to explain these results. Interestingly, the lifestyle of tree squirrels (i.e., diurnal activity, often spending nights in tree canopies) is quite similar to that of American crows, which are commonly exposed to WNV. Although some host-seeking mosquitoes tend to stay near ground level, ${ }^{30}$ others, possibly WNV competent vectors, do not. ${ }^{31}$ Thus, exposure of wildlife to WNV is certainly a complicated, multifaceted set of events, and the general behavior of select wildlife species undoubtedly plays a major role in the overall chance of exposure, especially from mosquitoes.

An alternative scenario for tree squirrel exposure to WNV is that the cavities or nests used by these squirrels are suitable habitat for a competent insect vector. For example, some mosquito species often breed in tree cavities. ${ }^{32}$ Furthermore, Sixl and others ${ }^{33}$ noted that experimental mice placed in ectoparasite-infested swallow nests showed evidence of antibodies against WNV. Thus, the ectoparasites of tree squirrels, especially those found primarily in nest cavities, could be an important facet of the high WNV antibody prevalence noted in these species.

Other sciurids tested such as black-tailed prairie dogs and eastern chipmunks showed no evidence of WNV antibodies. There are several possible explanations for this. First, the life history characteristics of these species could expose them to competent vectors less often. Second, these species may be exceptionally susceptible to WNV infection and typically die from the infection and are rarely recovered due to their small size (chipmunks) or fossorial lifestyle (prairie dogs). Third, these species could somehow be resistant to infection.

Meso-predators. Although small sample sizes were obtained, the high antibody prevalence rates of WNV detected for Virginia opossums $(N=10 ; 50.0 \%)$ and raccoons $(N=2$; $100 \%$; Tables 2-5) warrants further discussion. Recently, Komar and others ${ }^{6}$ provided evidence that select bird species seroconverted after eating WNV-infected animals, as was the case with cats. ${ }^{17}$ Further, naturally occurring prey to predator transmission has been postulated for a raptor species. ${ }^{15}$ Perhaps, mammals that are at least partially carnivorous (i.e., predation or scavenging) have increased risks of WNV infection because they may be susceptible to at least two means of transmission: arthropod-borne and dietary acquisition. Notably, these meso-predators have a lifestyle characteristic in common with tree squirrels, as both raccoons (commonly) and opossums (occasionally) can be found in trees.

Alternative vectors. Many WNV seronegative mammals within the Bronx Zoo/Wildlife Conservation Park were present immediately adjacent to or in the same enclosures as seropositive birds ${ }^{10}$ indicating the presence of ornithophilic mosquitoes at this site. Thus, bridge vectors, requiring a mos- 
TABLE 5

Summary of flavivirus and West Nile virus serological assays: Delaware and Philadelphia counties, Pennsylvania, 2003

\begin{tabular}{|c|c|c|c|c|c|c|c|}
\hline & & & & $6 \mathrm{~B} 6 \mathrm{C}-1$ & $3.1112 \mathrm{G} \ddagger$ & WNV PRNT§ & SLEV PRNT\& \\
\hline $\begin{array}{c}\text { Site } \\
\text { (trap-nights) }\end{array}$ & Species & $\mathrm{n}^{*}$ & $\mathrm{n}_{\mathrm{t}}^{\dagger}$ & $\begin{array}{l}\text { Positive } \\
\text { n (\%) }\end{array}$ & $\begin{array}{l}\text { Positive } \\
\text { n (\%) }\end{array}$ & $\begin{array}{l}\text { No. confirmed } \\
\text { (titer range) }\end{array}$ & $\begin{array}{l}\text { No. confirmed } \\
\text { (titer range) }\end{array}$ \\
\hline TSA & Sciurus carolinensis & 2 & 2 & $1(50.0)$ & $0(0.0)$ & & \\
\hline \multirow[t]{4}{*}{$(300)$} & Zapus hudsonius & 1 & 1 & $0(0.0)$ & $0(0.0)$ & & \\
\hline & Mus musculus & 2 & 2 & $2(100.0)$ & $0(0.0)$ & & \\
\hline & Peromyscus spp.【I & 17 & 13 & $4(30.8)$ & $0(0.0)$ & & \\
\hline & TSA combined & 22 & 18 & $7(38.9)$ & $0(0.0)$ & $n t^{\|}$ & $\mathrm{nt}$ \\
\hline TSB & Sciurus carolinensis & 3 & 1 & $1(100.0)$ & $1(100.0)$ & $1(160)$ & \\
\hline \multirow{3}{*}{$(200)$} & Peromyscus spp.II & 12 & 10 & $1(10.0)$ & $0(0.0)$ & & \\
\hline & Microtus pennsylvanicus & 3 & 2 & $0(0.0)$ & - & & \\
\hline & TSB combined & 18 & 13 & $2(15.4)$ & $1(7.7)$ & $1(160)$ & 0 \\
\hline PSA & Sciurus carolinensis & 4 & 4 & $3(75.0)$ & $3(75.0)$ & $3(320->1,280)$ & \\
\hline \multirow[t]{6}{*}{ (400) } & Blarina brevicauda & 4 & 4 & $1(25.0)$ & $0(0.0)$ & & \\
\hline & Mus musculus & 1 & 1 & $0(0.0)$ & $0(0.0)$ & & \\
\hline & Peromyscus spp.II & 3 & 2 & $1(50.0)$ & $0(0.0)$ & & \\
\hline & Didelphis virginiana & 2 & 2 & $2(100.0)$ & $2(100.0)$ & $2(160->1,280)$ & \\
\hline & Procyon lotor & 1 & 1 & $1(100.0)$ & $1(100.0)$ & $1(640)$ & \\
\hline & PSA combined & 15 & 14 & $8(57.1)$ & $6(42.8)$ & 6 & 0 \\
\hline PSB & Sciurus carolinensis & 2 & 2 & $2(100.0)$ & $1(50.0)$ & $1(640)$ & \\
\hline \multirow[t]{5}{*}{ (400) } & Blarina brevicauda & 1 & 1 & $1(100.0)$ & $0(0.0)$ & & \\
\hline & Peromyscus spp.II & 1 & 1 & $0(0.0)$ & - & & \\
\hline & Tamias striatus & 3 & 3 & $2(66.7)$ & $0(0.0)$ & & \\
\hline & Procyon lotor & 1 & 1 & $1(100.0)$ & $0(0.0)$ & $1 * *(320)$ & \\
\hline & PSB combined & 8 & 8 & $6(75.0)$ & $1(12.5)$ & $2(320-640)$ & 0 \\
\hline Pennsylvania & All sites and species combined & 63 & 53 & $23(43.4)$ & $9(17.0)$ & $9(160->1,280)$ & 0 \\
\hline
\end{tabular}

quito that is a general feeder, could be important for WNV cycles in mammals. ${ }^{12,34}$ Once mammalian populations become infected a new disease cycle could become established and maintained in locations where appropriate vector(s) are found or a separate transmission cycle could evolve. The possibility of atypical vectors, e.g., ticks, also exists. ${ }^{35,36}$ The activity of these vectors, especially when associated with den or fossorial-oriented species, may be less temperature dependent for the active maintenance of the disease cycle. If this were the case, mammals could be important for the local maintenance of WNV. However, other scenarios such as select mammal species are dead end hosts that do not contribute to transmission cycles of WNV also exist. In general, mechanisms for WNV maintenance between periods of continuous transmission have not been well-characterized in most localities, but may also depend on alternative vectors and reservoir hosts. ${ }^{37}$ Overall, the role of mammalian species in the maintenance and amplification of WNV is unknown; ${ }^{9}$ however, Austgen and others ${ }^{17}$ recently reported that peak viremias in experimentally infected cats may support infection of mosquitoes, albeit with lower efficiency than many avian hosts.

In summary, the high WNV antibody prevalence rates among select mammal species documented in this study indicate that mammals need to be studied more thoroughly as potential reservoirs for WNV. If a single, widespread mammal species (e.g., fox squirrels) were to develop a reasonably high viremia sufficient for infecting mosquitoes or an alternative vector (making them reservoir competent), a new disease cycle could become established and maintained. Thus, a separate mammal-arthropod cycle could emerge and be an important factor for human and livestock health and safety.

To determine the roles of mammals in natural transmission cycles of WNV, more epidemiologic and experimental studies are needed. ${ }^{9}$ We have provided evidence of WNV exposure in at least eight species of wild mammals from several geographical regions in the United States. Some species showed consistent evidence of WNV exposure among multiple states while others showed little or no evidence. Whether the latter is due to species-specific behavior, vector preference, or that select species may often die of WNV infection making seroconversions difficult to detect remains undetermined. Nonetheless, these data lend support to the use of tree squirrels as a means to monitor WNV activity at select locations. The commonly peri-domestic tendencies, relatively large size, and ease of observation of both eastern gray and fox squirrels may make them ideal sentinels for monitoring WNV in urban and suburban settings. However, because these species can live for multiple years, age structure of tree squirrel populations would need to be taken into account, as the presence of WNV antibodies may not reflect current year transmission in older animals.

While these data lend insights into the exposure of several wild mammal species to WNV, many questions remain. Two particularly intriguing questions to be investigated are what are the durations and levels of viremia in peridomestic mammals and what is the potential of direct transmission among these species. To address these topics, WNV challenge and contact-control studies will be conducted in the near future at the National Wildlife Research Center. 
TABLE 6

Summary of mammalian West Nile virus serological assays: central and eastern United States, 2003

\begin{tabular}{|c|c|c|c|c|c|c|c|}
\hline \multirow[b]{2}{*}{$\begin{array}{l}\text { Order (family) } \\
\text { Subfamily }\end{array}$} & \multirow[b]{2}{*}{ Species } & \multirow[b]{2}{*}{$\mathrm{n}^{*}$} & \multirow[b]{2}{*}{$\mathrm{n}_{\mathrm{t}}^{\dagger}$} & \multirow{2}{*}{$\begin{array}{c}\text { 6B6C-1 } \\
\begin{array}{c}\text { Positive } \\
\text { n }(\%)\end{array}\end{array}$} & \multirow{2}{*}{$\frac{3.1112 \mathrm{G} \doteqdot}{\begin{array}{c}\text { Positive } \\
\mathrm{n}(\%)\end{array}}$} & \multirow{2}{*}{$\frac{\text { WNV PRNT§ }}{\begin{array}{c}\text { No. } \\
\text { confirmed }\end{array}}$} & \multirow{2}{*}{$\frac{\text { SLEV PRNT }}{\begin{array}{c}\text { No. } \\
\text { confirmed }\end{array}}$} \\
\hline & & & & & & & \\
\hline \multicolumn{8}{|l|}{ Rodentia (Muridae) } \\
\hline \multirow[t]{4}{*}{ Sigmodontinae } & Neotoma mexicana & 1 & 1 & $0(0.0)$ & - & & \\
\hline & Peromyscus spp.đI & 178 & 158 & $44(27.8)$ & $0(0.0)$ & $7^{\|}$ & 1 \\
\hline & Peromyscus maniculatus & 41 & 41 & $17(41.5)$ & $0(0.0)$ & & \\
\hline & Reithrodontomys megalotis & 13 & 13 & $4(30.8)$ & $0(0.0)$ & & \\
\hline \multirow[t]{3}{*}{ Murinae } & Mus musculus & 29 & 19 & $10(52.6)$ & $1(5.3)$ & 1 & \\
\hline & Rattus norvegicus & 15 & 15 & $1(2.2)$ & $0(0.0)$ & & \\
\hline & Rattus spp.** & 70 & 46 & $13(28.3)$ & $1(6.7)$ & & \\
\hline \multirow[t]{2}{*}{ Arvicolinae } & Microtus pennsylvanicus & 12 & 10 & $2(20.0)$ & $0(0.0)$ & & \\
\hline & Microtus ochrogaster & 8 & 8 & $0(0.0)$ & $0(0.0)$ & & \\
\hline \multirow[t]{6}{*}{ (Sciuridae) } & Cynomys ludovicianus & 36 & 27 & $0(0.0)$ & $0(0.0)$ & & $1+\dagger$ \\
\hline & Marmota monax & 2 & 2 & $0(0.0)$ & $0(0.0)$ & & \\
\hline & Sciurus carolinensis & 31 & 29 & $22(75.9)$ & $14(48.3)$ & 12 & \\
\hline & Sciurus niger & 58 & 53 & $32(60.4)$ & $26(49.1)$ & 26 & \\
\hline & Tamiasciurus hudsonicus & 1 & 1 & $0(0.0)$ & $0(0.0)$ & $1 \div \div$ & \\
\hline & Tamias striatus & 38 & 35 & $10(28.6)$ & $0(0.0)$ & & \\
\hline \multirow[t]{2}{*}{ (Zapodidae) } & Zapus hudsonius & 12 & 12 & $1(8.3)$ & $1(8.3)$ & & \\
\hline & Napaeozapus insignis & 3 & 3 & $1(33.3)$ & $0(0.0)$ & & \\
\hline Insectivora (Soricidae) & Blarina brevicauda & 45 & 24 & $17(70.8)$ & $0(0.0)$ & & \\
\hline Lagomorpha (Leporidae) & Sylvilagus floridanus & 4 & 4 & $1(25.0)$ & $0(0.0)$ & & \\
\hline Carnivora (Procyonidae) & Procyon lotor & 2 & 2 & $2(100.0)$ & $1(50.0)$ & $2 \S \S$ & \\
\hline Marsupialia (Didelphidae) & Didelphis virginiana & 10 & 10 & $7(70.0)$ & $5(50.0)$ & 5 & \\
\hline Central and eastern U.S. & All sites and species combined & 609 & 513 & $184(35.9)$ & $53(10.3)$ & 54 & 2 \\
\hline \multicolumn{8}{|c|}{$\begin{array}{l}* \text { Total number of individuals trapped. } \\
\dagger \text { Total number of individuals tested by blocking ELISA. }\end{array}$} \\
\hline \multicolumn{8}{|c|}{$\begin{array}{l}\text { Total number of individuals tested by blocking ELISA. } \\
\text { Only sera samples that tested positive using 6B6C-1 MAb (and borderline negatives) were tested using } 3.1112 \mathrm{G} \text { MAb. Prevalence estimates (\% pos) are based on the whole sample size (i.e. }\end{array}$} \\
\hline \multicolumn{8}{|c|}{ it is assumed that sera negative using MAb 6B6C-1 would be negative using MAb 3.1112G). Some sera samples had insufficient volumes to conduct tests with 3.1112G MAb and PRNT methods. } \\
\hline \multirow{2}{*}{\multicolumn{8}{|c|}{$\begin{array}{l}\text { § PRNTs (for both West Nile virus and Saint Louis encephalitis virus) were conducted on sera samples with sufficient volume. } \\
\text { 『I Peromyscus leucopus and P. maniculatus combined where sympatric. } \\
\text { "A total of seven Peromyscus mice were negative for WNV antibodies using ELISA tests but positive using PRNTs. }\end{array}$}} \\
\hline & & & & & & & \\
\hline \multicolumn{8}{|c|}{$\begin{array}{l}\text { II Peromyscus leucopus and } P \text {. maniculatus combined where sympatric. } \\
\text { A total of seven Peromyscus mice were negative for WNV antibodies using ELISA tests but positive using PRNTs. } \\
\text { ** Six individuals which are not members of the genus Rattus (likely Oryzomys palustris) were erroneously included in total. }\end{array}$} \\
\hline \multicolumn{8}{|c|}{$\begin{array}{l}\text { † One black-tailed prairie dog was negative using 6B6C-1 MAb but was positive for Saint Louis encephalitis virus antibodies using PRNTs. } \\
\text { Borderline positive using 6B6C-1 MAb. }\end{array}$} \\
\hline
\end{tabular}

Received October 7, 2004. Accepted for publication December 4, 2004.

Acknowledgments: We are indebted to T. Saab (NWRC), P. Oesterle (NWRC), B. Blackwell (NWRC Sandusky Field Station), NWRC Sandusky Field Station personnel, A. Montoney (OH Wildlife Services), Ohio Wildlife Services Operations personnel, R. Chipman (NY Wildlife Services), K. Preusser (NY Wildlife Services), J. Suckow (PA Wildlife Services) and D. LeBlanc (LA Wildlife Services) for field/logistical assistance, H. Sullivan (NWRC) and K. Bentler (NWRC) for field and laboratory assistance, and B. Blitvich (CSU) for laboratory reagents and advice. The authors thank multiple stewards of public lands in the Fort Collins vicinity, private landowners from Columbia County, NY, land stewards from Albany County, NY, John Heinz National Wildlife Refuge, Fairmont Park Commission, Vector Control Services, Philadelphia, PA, Bucks County Department of Parks and Recreation, C. Furlo (USDA, Wildlife Services), and private land stewards from Calcasieu Parish, LA, for logistical support. Comments from two anonymous reviewers improved an earlier version of this manuscript.

Financial support: Funding for this work was provided by the U.S. Centers for Disease Control and Prevention (LC: CDC IAA no. 03FED12031 (to USDA) and CDC-US3/CCU820510 (to CSU) and the United States Department of Agriculture.

Author's addresses: J. Jeffrey Root, Jeffrey S. Hall, Robert G. McLean, and Larry Clark, National Wildlife Research Center, USDA/APHIS/WS, 4101 La Porte Ave., Fort Collins, CO 80521, Telephone: 970-266-6000, Fax: 970-266-6138, E-mails: jeff.root@ aphis.usda.gov, jeffery.s.hall@aphis.usda.gov, robert.g.mclean@aphis. usda.gov, larry.clark@aphis.usda.gov. Nicole L. Marlenee and Barry J. Beaty, Arthropod-borne and Infectious Diseases Laboratory, Department of Microbiology, Immunology, and Pathology, Colorado State University, Fort Collins, CO 80523, Telephone: 970-491-2988, Fax: 970-491-8323, E-mails: marlenee@colostate.edu and bbeaty@ colostate.edu. Justin Gansowski, New York Wildlife Services, USDA, 1930 Route 9, Castleton, NY 12033, Telephone: 518-4774837, Fax: 518-477-4899, E-mail: justin.gansowski@aphis.usda.gov.

Reprint requests: Dr. Larry Clark, National Wildlife Research Center, 4101 LaPorte Ave., Fort Collins, CO 80521.

\section{REFERENCES}

1. Centers for Disease Control and Prevention, 1999. Outbreak of West Nile-like viral encephalitis - New York, 1999. $M M W R$ 48: 845-849.

2. Lanciotti RS, Roehrig JT, Deubel V, Smith J, Parker M, Steele K, Crise B, Volpe KE, Crabtree MB, Scherret JH, Hall RA, MacKenzie JS, Cropp CB, Panigraphy B, Ostlund E, Schmitt B, Malkinson M, Banet C, Weissman J, Komar N, Savage HM, Stone W, McNamara T, Gubler DJ, 1999. Origin of the West Nile virus responsible for an outbreak of encephalitis in the northeastern United States. Science 286: 2333-2337.

3. Centers for Disease Control and Prevention, 1999. Update: West Nile virus encephalitis - New York, 1999. MMWR 48: 944-946, 955.

4. Centers for Disease Control and Prevention, 2003. West Nile virus activity - United States, November 20-25, 2003. MMWR 52: 1160.

5. Blitvich BJ, Fernandez-Salas I, Contreras-Cordero JF, Marlenee NL, Gonzalez-Rojas JI, Komar N, Gubler DJ, Calisher CH, Beaty BJ, 2003. Serologic evidence of West Nile virus infection in horses, Coahuila State, Mexico. Emerg Infect Dis 9: 853-856.

6. Komar O, Robbins MB, Klenk K, Blitvich BJ, Marlenee NL, Burkhalter KL, Gubler DJ, Gonzálvez G, Peña CJ, Peterson AT, Komar N, 2003. West Nile virus transmission in resident birds, Dominican Republic. Emerg Infect Dis 9: 1299-1302. 
7. Dupuis AP II, Marra PP, Kramer LD, 2003. Serologic evidence of West Nile virus transmission, Jamaica, West Indies. Emerg Infect Dis 9: 860-863.

8. Heinz FX, Collett MS, Purcell RH, Gould EA, Howard CR, Houghton M, Moormann RJM, Rice CM, Thiel JJ, 2000. Family Flaviviridae. Virus taxonomy. Van Regenmortel CM, Fauquet CM, Bishop DHL, Carstens E, Estes MK, Lemon S, Manilogg J, Mayo MA, McGeoch DJ, Pringle CR, Wickner RB, eds. Seventh Report of the International Committee on Taxonomy of Viruses. San Diego, CA: Academic Press, 859-878.

9. Mclean RG, Ubico SR, Bourne D, Komar N, 2002. West Nile virus in livestock and wildlife. Curr Top Microbiol Immunol 267: 271-308.

10. Ludwig GV, Calle PP, Mangiafico JA, Raphael BL, Danner DK, Hile JA, Clippinger TL, Smith JF, Cook RA, McNamara T, 2002. An outbreak of West Nile virus in a New York City captive wildlife population. Am J Trop Med Hyg 67: 67-75.

11. Blitvich BJ, Bowen RA, Marlenee NL, Hall RA, Bunning ML, Beaty BJ, 2003. Epitope-blocking enzyme-linked immunosorbent assays for detection of West Nile virus antibodies in domestic mammals. J Clin Microbiol 41: 2676-2679.

12. Turell MJ, O'Guinn ML, Dohm DJ, Jones JW, 2001. Vector competence of North American mosquitoes (Diptera: Culicidae) for West Nile virus. J Med Entomol 38: 130-134.

13. Goddard LB, Roth AE, Reisen WK, Scott TW, 2002. Vector competence of California mosquitoes for West Nile virus. Emerg Infect Dis 8: 1385-1391.

14. Tempelis $\mathrm{CH}, 1975$. Host-feeding patterns of mosquitoes, with a review of advances in analysis of blood meals by serology. $J$ Med Entomol 11: 635-653.

15. Garmendia AE, Van Kruiningen HJ, French RA, Anderson JF, Andreadis TG, Kumar A, West B, 2000. Recovery and identification of West Nile virus from a hawk in winter. J Clin Microbiol 38: 3110-3111.

16. Komar N, Langevin S, Hinten S, Nemeth N, Edwards E, Hettler D, Davis B, Bowen R, Bunning M, 2003. Experimental infection of North American birds with the New York 1999 strain of West Nile Virus. Emerg Infect Dis 9: 311-322.

17. Austgen LE, Bowen RA, Bunning ML, Davis BS, Mitchell CJ, Chang G-JJ, 2004. Experimental infection of cats and dogs with West Nile virus. Emerg Infect Dis 10: 82-86.

18. McLean RG, Ubico SR, Docherty DE, Hansen WR, Sileo L, McNamara TS, 2001. West Nile virus transmission and ecology in birds. Ann N Y Acad Sci 951: 54-57.

19. Trock SC, Meade BJ, Glaser AL, Ostlund EN, Lanciotti RS, Cropp BC, Kulasekera V, Kramer LD, Komar N, 2001. West Nile outbreak among horses in New York state, 1999 and 2000. Emerg Infect Dis 7: 745-747.

20. Komar N, Panella NA, Boyce E, 2001. Exposure of domestic mammals to West Nile virus during an outbreak of human encephalitis, New York City, 1999. Emerg Infect Dis 7: 736738.

21. Kramer LD, Bernard KA, 2001. West Nile virus infection in birds and mammals. Ann N Y Acad Sci 951: 84-93.

22. Anderson JF, Vossbrinck CR, Andreadis TG, Iton A, Beckwith WH III, Mayo DR, 2001. Characterization of West Nile virus from five species of mosquitoes, nine species of birds, and one mammal. Ann N Y Acad Sci 951: 328-331.

23. Farajollahi A, Panella NA, Carr P, Crans W, Burguess K, Komar N, 2003. Serologic evidence of West Nile virus infection in black bears (Ursus americanus) from New Jersey. J Wildl Dis 39: 894-896.

24. Beaty BJ, Calisher CH, Shope RE, 1995. Arboviruses. Lennette EH, Lennette DA, Lennette ET, eds. Diagnostic procedures for viral, rickettsial, and chlamydial infections. Seventh edition. Washington, DC: American Public Health Association, 89-212.

25. Komar N, Panella NA, Burns JE, Dusza SW, Mascarenhas TM, Talbot TO, 2001. Serologic evidence for West Nile virus infection in birds in the New York City vicinity during an outbreak in 1999. Emerg Infect Dis 7: 621-625.

26. Kuno G, Chang G-JJ, Tsuchiya KR, Karabatsos N, Cropp CB, 1998. Phylogeny of the genus Flavivirus. J Virol 72: 73-83.

27. Varelas-Wesley I, Calisher CH, 1982. Antigenic relationships of flaviviruses with undetermined arthropod-borne status. Am J Trop Med Hyg 31: 1273-1284.

28. Kiupel M, Simmons HA, Fitzgerald SD, Wise A, Sikarskie JG, Cooley TM, Hollamby SR, Maes R, 2003. West Nile virus infection in eastern fox squirrels (Sciurus niger). Vet Pathol 40: 703-707.

29. Heinz-Taheny KM, Andrews JJ, Kinsel MJ, Pessier AP, Pinkerton ME, Lemberger KY, Novak RJ, Dizikes GJ, Edwards E, Komar N, 2004. West Nile virus infection in free-ranging squirrels in Illinois. J Vet Diagn Invest 16: 186-190.

30. Bosak PJ, Reed LM, Crans WJ, 2001. Habitat preference of hostseeking Coquillettidia perturbans (Walker) in relation to birds and eastern equine encephalomyelitis virus in New Jersey. $J$ Vector Ecol 26: 103-109.

31. Anderson JF, Andreadis TG, Main AJ, Kline DL, 2004. Prevalence of West Nile virus in tree canopy-inhabiting Culex pipiens and associated mosquitoes. Am J Trop Med Hyg 71: 112119.

32. Crans WJ, Crans SC, 1998. Aedes thibaulti in northern New Jersey. J Am Mosq Control Assoc 14: 348-350.

33. Sixl W, Stunzner D, Withalm H, 1988. Serological examination for antibodies against West Nile virus, Semlikivirus and Chikungunyavirus in laboratory mice, parasitized by nidicole fauna from swallow's nests. Geogr Med Suppl 1: 51-55.

34. Apperson CS, Harrison BA, Unnasch TR, Hassan HK, Irby WS, Savage HM, Aspen SE, Watson DW, Rueda LM, Engber BR, Nasci RS, 2002. Host-feeding habits of Culex and other mosquitoes (Diptera: Culicidae) in the Borough of Queens in New York City, with characters and techniques for identification of Culex mosquitoes. J Med Entomol 39: 777-785.

35. Blackburn NK, Reyers F, Berry WL, Shepherd AJ, 1989. Susceptibility of dogs to West Nile virus: a survey and pathogenicity trial. J Comp Pathol 100: 59-66.

36. Abbassy MM, Osman M, Marzouk AS, 1993. West Nile virus (Flaviviridae: Flavivirus) in experimentally infected Argas ticks (Acari: Argasidae). Am J Trop Med Hyg 48: 726-737.

37. Komar N, 2000. West Nile viral encephalitis. Rev Sci Tech 19: 166-176. 